\title{
Linking the thermal evolution and emplacement history of an upper-crustal pluton to its lower-crustal roots using zircon geochronology and geochemistry (southern Adamello batholith, N. Italy)
}

\author{
C. Broderick ${ }^{1} \cdot$ J. F. Wotzlaw ${ }^{1} \cdot$ D. A. Frick ${ }^{2} \cdot$ A. Gerdes $^{3} \cdot$ A. Ulianov ${ }^{4} \cdot$ D. Günther ${ }^{2}$. \\ U. Schaltegger ${ }^{1} \mathbb{D}$
}

Received: 25 November 2014 / Accepted: 13 August 2015 / Published online: 1 September 2015

(C) Springer-Verlag Berlin Heidelberg 2015

\begin{abstract}
The Val Fredda igneous complex in the southern Adamello batholith (N. Italy) consists of dioritic to gabbroic sills and dykes that were injected at $6-10 \mathrm{~km}$ depth into partly crystallized tonalites and granodiorites. High-precision $\mathrm{U}-\mathrm{Pb}$ age determinations by chemical abrasion-isotope dilution-thermal ionization mass spectrometry (CA-ID-TIMS) show very similar dispersion of zircon U-Pb dates over 90-200 ka and identical age distributions with a dominant mode at $42.5 \mathrm{Ma}$ for six samples ranging in composition from gabbro to granodiorite. The co-variation of the probability density curves of zircon dates from mafic and felsic units suggests that they shared a common thermal history with periods of enhanced and reduced zircon growth, reflecting lowered and increased magma temperatures, respectively. However, trace element compositions, Ti-in-zircon temperatures and Hf isotopic compositions of zircon from mafic lithologies are distinctly
\end{abstract}

Communicated by Othmar Müntener.

Electronic supplementary material The online version of this article (doi:10.1007/s00410-015-1184-x) contains supplementary material, which is available to authorized users.

U. Schaltegger

urs.schaltegger@unige.ch

1 Department of Earth Sciences, University of Geneva, rue des Maraîchers 13, 1205 Geneva, Switzerland

2 Laboratory of Inorganic Chemistry, Swiss Federal Institute of Technology ETH Zürich, Vladimir-Prelog-Weg 1, 8093 Zurich, Switzerland

3 Institute of Geosciences, Goethe-University Frankfurt, Altenhöferallee 1, 60438 Frankfurt, Germany

4 Earth Sciences, University of Lausanne, Géopolis, 1015 Lausanne, Switzerland different from those in felsic zircon and suggest their crystallization occurred in isotopically and chemically diverse magma batches. These magma batches formed in the lower crust from mingling and mixing of residual melts (derived from fractional crystallization of mainly amphibole from basaltic melt) with crustal partial melts at high temperatures above zircon saturation. Zircons crystallized during incipient cooling of these magmas and were entrained into the ascending melts, which were emplaced and rapidly solidified in the upper crust. The reported age dispersions imply that fractional crystallization and hybridization in the lower-to-middle crust, ascent into the upper crust and solidification did not last for more than $200 \mathrm{ka}$. The small magma volumes and flux also preclude significant zircon crystallization at the upper crustal emplacement level.

Keywords Pluton - Zircon $\cdot \mathrm{U}-\mathrm{Pb}$ dating $\cdot$ Trace elements $\cdot \mathrm{Hf}$ isotopes $\cdot$ Magmatism $\cdot$ Adamello

\section{Introduction}

A growing body of evidence supports the notion that plutons are incrementally assembled by repeated magma injections (Michel et al. 2008; Annen et al. 2006; Annen 2011; Miller et al. 2011; de Saint Blanquat et al. 2011; Leuthold et al. 2012) and eventually build up batholiths over extended periods of time. Timescales of pluton construction were reported to vary from $10^{4}$ to $10^{6}$ years (Glazner et al. 2004; Coleman et al. 2004; Matzel et al. 2006; Michel et al. 2008; Schaltegger et al. 2009; Leuthold et al. 2012; Schoene et al. 2012; Wotzlaw et al. 2012; Chelle-Michou et al. 2014). Using high-precision chemical abrasion-isotope dilution thermal-ionization mass spectrometry (CAID-TIMS) U-Pb zircon geochronology, it is possible to 
resolve individual magma pulses and to track both the thermal and crystallization histories of magmatic systems at high temporal resolution (e.g., Wotzlaw et al. 2013).

During periods of repeated magma injections, temperature, crystal content and composition will fluctuate within magma batches, and conditions potentially alternate between zircon saturation and undersaturation, which will lead to intermittent periods of crystallization and resorption/partial dissolution. Following episodes of reheating and rejuvenation, zircon dates will record periods of enhanced zircon crystallization associated with cooling below the maximum temperature of zircon saturation (Watson and Harrison 1983; Hanchar and Watson 2003; Boehnke et al. 2013). This is reflected by a distinct mode in $\mathrm{U}-\mathrm{Pb}$ age distribution curves and translates into an increased proportion of zircon crystals of a similar age in individual magma batches (e.g., Claiborne et al. 2010; Vazquez and Reid 2004; Wotzlaw et al. 2012, 2013; Cashman and Blundy 2013; Cooper and Kent 2014). High-precision CA-ID-TIMS dating techniques applied to zircon have the potential to resolve the periodicity of temperature fluctuations in a magmatic system at lower or intermediate crustal levels over the time interval the magma remained zircon-saturated. However, such dates are obtained from whole zircon grains or grain fragments and are potentially integrated over complex and protracted growth histories. Spatially resolved U-Pb dates, on the other hand, do not offer the necessary 10-100 ka precision for resolving the timing of magmatic processes in most pre-Pleistocene systems (e.g., Schmitt 2011; Schaltegger et al. 2015).

We here study the timing of magmatic processes in a small, peripheral pluton of the southern Adamello batholith, relating the high-precision $\mathrm{U}-\mathrm{Pb}$ zircon crystallization dates to the thermal evolution of the magmatic system. We also try to establish the link between the presently visible intrusive relationships at upper-crustal paleodepth and the magmatic processes in the deeper crustal root zone of the magmatic system. We apply CA-ID-TIMS zircon geochronology combined with trace element and $\mathrm{Hf}$ isotope analyses in zircon, to the Val Fredda Complex (VFC) in the southern tip of the Adamello Batholith, N. Italy (Fig. 1), in order to study the magmatic processes at the onset of the formation of an upper-crustal pluton.

The VFC has been constructed through multiple injections of small volumes of compositionally diverse magmas, ranging from gabbro to granodiorite. Field observations reveal complex relationships among mafic magma injected as sills into solidifying felsic magma, where both magma mingling and hybridization can be observed. We can (1) show that the use of chemical composition combined with age diversity of crystallized zircon can document the buildup and the thermal evolution of a magmatic pulse at a crustal scale; (2) describe the processes that blend magmas of different compositions and sources into hybrids; and (3) estimate the involved magmatic volumes. We further present a conceptual model of the processes recorded by zircon, starting from crystallization in the deep crustal magmatic-processing zone, mixing of residual with partial crustal melts into hybrids, entrainment of already crystallized mineral phases into ascending melts and mixing with crustal partial melts, to the physical emplacement and rapid solidification of magmas in the upper crust.

\section{Geologic setting}

The Adamello batholith is exposed over an area of $670 \mathrm{~km}^{2}$ with $\sim 2 \mathrm{~km}$ of vertical relief in the Southern Alps, Northern Italy (Fig. 1a). It is one of the intrusive bodies of the Alpine orogen that was emplaced during Eocene and Oligocene along the Periadriatic fault system, at the intersection of the Tonale and Giudicarie faults, following the collision of European and Adriatic plates. Despite its accepted post-collisional nature, it is composed of an association of tonalites, trondhjemites and granodiorites with minor mafic units in the southernmost part of the batholith (Brack 1983; Callegari and Brack 2002) that are considered to be typical of a continental magmatic arc setting. Geochronological data indicate that the Adamello batholith was sequentially constructed between $43 \mathrm{Ma}$ (southern and eastern marginal units) and $33 \mathrm{Ma}$ (northeastern marginal units; Del Moro et al. 1983; Hansmann and Oberli 1991; Skopelitis 2014). Strontium and O isotopic studies reflect an increasing amount of crustal assimilation during the sequential emplacement of the batholith (Cortecci et al. 1979; Del Moro et al. 1983; Skopelitis 2014). The batholith has been divided into so-called super-units (Callegari and Brack 2002), with the apparent size of the sub-intrusions and degree of homogeneity increasing northwards (Fig. 1a). The oldest rocks of the Adamello batholith are recorded in the Corno Alto and the southernmost Re di Castello units, including the $\sim 43 \mathrm{Ma}$ Corno Alto granodiorites (Del Moro et al. 1983; Skopelitis 2014), the 42.43 Ma Monte Frerone granite dykes (Schaltegger et al. 2009) and the $\sim 42 \mathrm{Ma}$ Val Fredda Complex (VFC; Hansmann and Oberli 1991; Tiepolo et al. 2011). In addition to representing one of the oldest parts of the Adamello batholith, the Re di Castello super-unit shows the most compositional diversity with ultramafic-to-mafic units spatially associated with tonalites and granodiorites. The mafic rocks occur mainly in the periphery and are best exposed in the Val Fredda and the Blumone complexes (Ulmer et al. 1983; Blundy and Sparks 1992; Tiepolo and Tribuzio 2005, Tiepolo et al. 2011).

This study focuses on the VFC, a small marginal intrusion exposed over $\sim 6 \mathrm{~km}^{2}$ in the southernmost part of the Adamello batholith (Fig. 1b). The VFC is bordered in the 
Fig. 1 a Simplified geologic map of the Adamello batholith after Schaltegger et al. (2009), showing the four super-units and corresponding lithologies. Location of field area in Fig. 1 b is outlined. b Simplified geologic map of the Val Fredda Complex modified after Blundy and Sparks (1992).

Sample locations are indicated by symbols: $C G$ Cadino gabbro, $M F G$ marginal facies granodiorite, $M G, A D 9, C S 23$ Mattoni gabbro, $P E G$ pegmatite, $P Q D$ plagioclase quartz diorite, $V F T$ Val Fredda tonalite
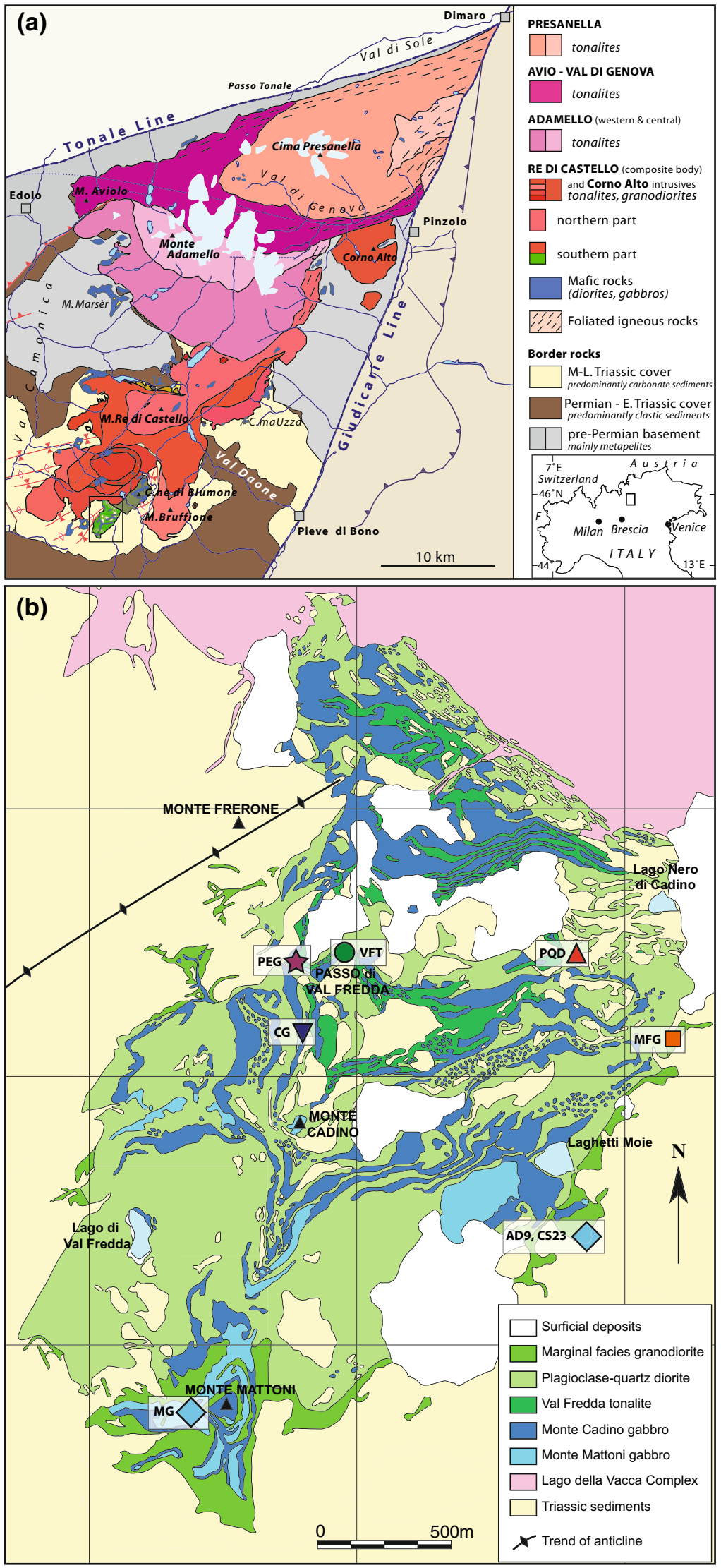

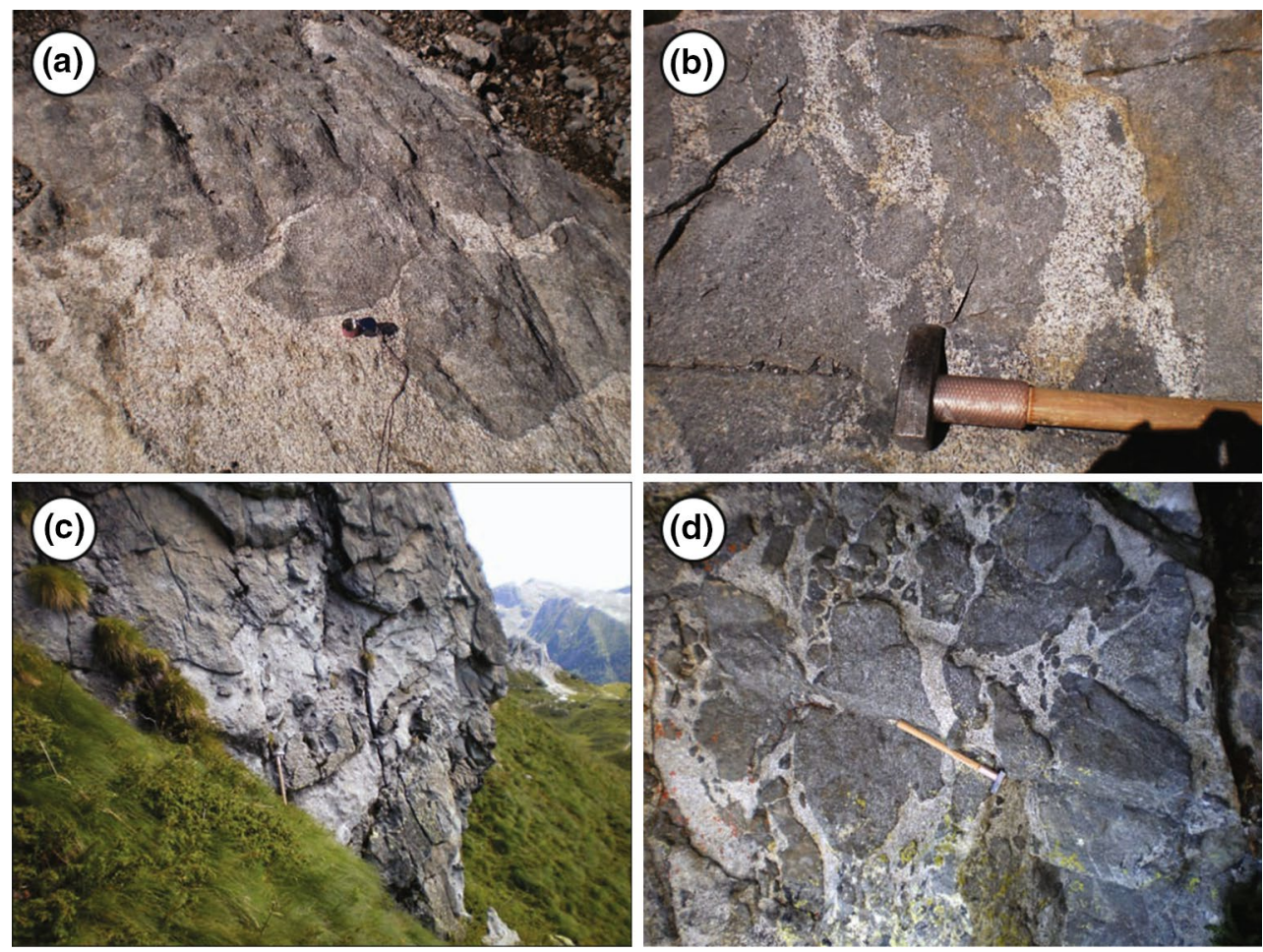

Fig. 2 Outcrop photogarphs of studied lithologies; a lobate mafic sheets chilled against marginal facies granodiorite; $\mathbf{b}$ various degrees of mingling and mixing between mafic melts and felsic crystal

east, west and south by Triassic dolomite country rocks, which exhibit pre-intrusive ENE-WSW striking largescale folds (Brack 1983; Callegari and Brack 2002) and is itself located within a broad syncline and bound to the west by the steep sub-vertical eastern limb of the Frerone anticline, suggesting that the pre-intrusive folds in the Triassic country rocks influenced the emplacement of the VFC. Roof pendants and stoped blocks up to $300 \mathrm{~m}$ across the dolomite country rocks are abundant throughout the VFC (Fig. 1b) and suggest that the VFC is presently exposed near the roof of its intrusion (Brack 1983; Blundy and Sparks 1992). The VFC is bordered in the north by the 42.07-41.76 Ma old Lago della Vacca Complex (LVC; Schoene et al. 2012). The "forceful" emplacement of the LVC caused north-south shortening in the VFC close to the contact, leading to flattening of mafic enclaves and stoped dolomite blocks in the plane parallel to the contact (Fig. 1b; John and Blundy 1993).

Based on detailed fieldwork (Brack 1983; Ulmer et al. 1983; Blundy and Sparks 1992), the VFC intrusion was described as a complex system where felsic magmas, crystallizing in the roof of a larger magmatic system, were injected by horizontal mafic sheets of variable thickness ( $\sim .5 \mathrm{~m}$ up to $100 \mathrm{~m}$ ). The mafic magmas that form the Mattoni and Cadino gabbros (Fig. 1b) were quenched mushes; c Cadino mafic sheets injected laterally into partially crystallized plagioclase quartz-diorite; $\mathbf{d}$ break-up of mafic sheets into enclave swarms

to temperatures of $\sim 950{ }^{\circ} \mathrm{C}$ corresponding to $\sim 40 \%$ crystals (Blundy and Sparks 1992). During their injection into crystallizing tonalitic magma, they partly disintegrated into enclaves due to the inversion of the rheology contrast during cooling, resulting in volume contraction and the formation of wavy and lobate sheet margins (Fig. 2c, d). Evidence for quenching comes from the presence of chilled margins on some of the enclaves and the mafic sheets. Upon cooling, the transfer of heat and hydrous volatiles was efficient enough to remelt and remobilize locally the felsic crystal mushes causing mingling and back-veining at the maficfelsic contacts (Fig. 2a), and hybridization (Fig. 2b).

The VFC consists of five distinct lithological units, displayed in Fig. 1b, and characteristic hand specimens are shown in Fig. S1 (electronic supplement). Zircons from one representative sample of each unit were analyzed for high-precision $\mathrm{U}-\mathrm{Pb}$ dates and chemical and $\mathrm{Hf}$ isotopic compositions. For petrographic description and wholerock chemical characteristics of these units, the reader is referred to Ulmer et al. (1983), and Blundy and Sparks (1992). (1) The marginal facies granodiorite (MFG) is porphyritic and contains quartz, plagioclase, biotite, magnetite and accessory apatite, zircon and titanite (Fig. S1a); the MFG outcrops mainly along the southern and eastern margins; (2) the plagioclase quartz diorite (PQD) is 
equigranular and contains quartz, plagioclase, amphibole, biotite, magnetite and accessory apatite, zircon and titanite (Fig. S1b), which outcrops mainly in the central and northern parts; (3) the Val Fredda tonalite (VFT) is equigranular and contains quartz, plagioclase, amphibole, biotite, magnetite and accessory apatite, ilmenite, zircon and titanite, which outcrops mainly in the north of the complex (Fig. S1c); (4) the Mattoni gabbro (MG) occurs mainly in the southernmost part of the pluton near Monte Mattoni, and consist of hornblende-phyric, pyroxene-bearing gabbro sheets that are characterized texturally by prismatic euhedral hornblendes in a matrix of plagioclase, quartz and accessory apatite, zircon, titanite and calcite (Fig. S1d). Ultramafic cumulates (hornblendite) occur at the base of the Mattoni gabbro and consist of amphiboles that contain olivine, clinopyroxene, orthopyroxene and $\mathrm{Cr}$-spinel inclusions (Ulmer et al. 1983; Blundy and Sparks 1992; Tiepolo and Tribuzio 2005; Tiepolo et al. 2002, 2011); (5) the Cadino gabbro (CG) occurs throughout the pluton as a series of horizontal sheets separated by felsic units (PQD, VFT) of variable thickness ( $\mathrm{mm}$ to $\mathrm{m}$ scale) depending on the locality but outcrops most abundantly at Monte Cadino. The Cadino mafic rocks range from hornblende gabbros to quartz-diorites that are characterized texturally by elongate prismatic to acicular hornblendes in a matrix of plagioclase, quartz and accessory apatite, zircon and titanite (Fig. S1e). (6) The Cadino gabbro is spatially associated with coarse gabbro pegmatites, which occur as veins and pods cross-cutting the Mattoni and Cadino gabbroic units (Ulmer et al. 1983; Blundy and Sparks 1992). The dated pegmatite (sample PEG) shows acicular, skeletal hornblendes (Fig. S1f), which suggest high growth rates from supersaturated solutions. Because they typically occur layer-parallel near the top of the mafic sheets, the pegmatites are considered to represent the residual melts of the gabbros (Ulmer et al. 1983).

The unique occurrences of ultramafic-to-gabbroic units in the Re di Castello super unit have been the focus of many studies (Ulmer et al. 1983; Blundy and Sparks 1992; Tiepolo and Tribuzio 2005; Tiepolo et al. 2002, 2011, 2014) that provide insights into how the VFC was emplaced:

A three stage evolution has been advocated for the Mattoni gabbro by Tiepolo et al. (2011), invoking (1) crystallization of ultramafic anhydrous cumulates of olivine, clinoand orthopyroxene, and spinel from a subalkaline basaltic magma, which crystallized brown amphibole containing those minerals as inclusions; (2) intrusion of amphiboleforming liquids that subsequently reacted with these cumulates and disrupted them, forming a deep-seated magma at $1000-1100{ }^{\circ} \mathrm{C}$ and $0.8-1 \mathrm{GPa}$, crystallizing brownishgreen hornblende and, after a delay, plagioclase (Ulmer et al. 1983), and resulting in high-Mg andesitic residual melts (Tiepolo et al. 2011); and (3) transport of the recycled lower-crustal cumulates and crystal cargo by a volatilerich evolved melt that was emplaced in the shallow crust $(0.2-0.3 \mathrm{GPa})$ at $\sim 900{ }^{\circ} \mathrm{C}$ (Ulmer et al. 1983; Blundy and Sparks 1992; Nimis and Ulmer 1998; Tiepolo et al. 2011). To elucidate the suggested duration of more than 10 million years for this multi-stage evolution between 51 and $40 \mathrm{Ma}$ (Tiepolo et al. 2011), zircon from two additional samples of Mattoni gabbro slightly differing in texture and grainsize have been analyzed for their $\mathrm{U}-\mathrm{Pb}$ age by laser ablation inductively coupled plasma mass spectrometry (LAICP-MS) techniques (samples AD9 and CS23; Fig. S1 g, h) in order to complement the CA-ID-TIMS dates of sample MG.

The evolution of the Cadino gabbro is very different from the Mattoni gabbro: Experimental work by Blundy and Sparks (1992) shows that the crystallization sequence for the Cadino gabbro began with hornblende followed by plagioclase, and the lack of olivine and clinopyroxene, is the result of rapid cooling of a magma from 1000 to $1050{ }^{\circ} \mathrm{C}$ down to $\sim 950{ }^{\circ} \mathrm{C}$ during the rapid ascent into the upper crust. This is consistent with the observation of chilled margins along Cadino sheet edges and indicates that the acicular hornblendes are the result of rapid cooling and crystallization. The shallow emplacement is consistent with Al-in-hornblende geobarometry of $0.2-0.3 \mathrm{GPa}$ obtained for the felsic units (Stauffacher 2012).

\section{Analytical procedures}

\section{U-Pb geochronology by chemical abrasion-isotope dilution-thermal ionization mass spectrometry}

Zircon crystals were separated using standard magnetic and heavy liquid mineral separation techniques, and were handpicked under a binocular microscope. Inclusion-free zircons were selected from populations of various morphologies and sizes. Zircon grains were thermally annealed and chemically abraded (Mattinson 2005), in order to minimize lead loss, as a consequence of radioactive decay damage, which is essential for the interpretation of our zircon ages. A total of 70 zircon grains were analyzed for their $\mathrm{U}-\mathrm{Pb}$ isotopic composition using high-precision ID-TIMS techniques following protocols similar to those outlined by Wotzlaw et al. (2014b). They were spiked using the EARTHTIME (http://www.earth-time.org) ${ }^{202} \mathrm{~Pb}-{ }^{205} \mathrm{~Pb}-$ ${ }^{233} \mathrm{U}{ }^{235} \mathrm{U}$-tracer solution (calibration v. 3.0; Condon et al. 2015). All measurements were performed at the University of Geneva on a Thermo-Scientific TRITON thermal ionization mass spectrometer, and data reduction was done employing Tripoli and U-Pb Redux software (Bowring et al. 2011) that uses the algorithms of McLean et al. (2011). 
Zircon ${ }^{206} \mathrm{~Pb} /{ }^{238} \mathrm{U}$ dates were corrected for initial ${ }^{230} \mathrm{Th}$ disequilibrium assuming a constant Th-U zircon-melt partition coefficient ratio $\left(D_{\mathrm{Th} / \mathrm{U}}\right)$ of $0.2 \pm 0.1$, covering the range of most empirically and experimentally determined partition coefficients, and resulting in an increase in ${ }^{206} \mathrm{~Pb} /{ }^{238} \mathrm{U}$ dates by $87 \mathrm{ka}$ (see Wotzlaw et al. $2014 \mathrm{~b}$ for details). All uncertainties are reported at the $2 \sigma$ level. Data are presented in Table S1 of the electronic supplement.

\section{U-Pb geochronology by LA-ICP-MS}

A total of $45 \mathrm{U}-\mathrm{Pb}$ ages were analyzed on 38 zircon crystals from two samples of Mattoni gabbro. Isotopic measurements were done using a 193-nm excimer laser ablation system UP-193FX (New Wave) coupled to an ELEMENT 2 XR sector-field, single-collector ICP-MS (Thermo Scientific) at the University of Lausanne. Operating conditions were very similar to those described in Ulianov et al. (2012) and included a $35 \mu \mathrm{m}$ spot size combined with an on-sample energy density of $3 \mathrm{~J} / \mathrm{cm}^{2}$ and a repetition rate of $5 \mathrm{~Hz}$ to minimize the fractionation. Helium was used as a carrier gas (1.07 1/min). Synthetic glass SRM 612 from NIST was used to maximize the sensitivity and to control the oxide and doubly charged ion production rate during the instrument optimization. The instrument mass bias was calibrated by 40 measurements of one grain of reference zircon material GJ-1 (CA-ID-TIMS ${ }^{206} \mathrm{~Pb} /{ }^{238} \mathrm{U}$ age of $600.5 \pm 0.4 \mathrm{Ma}$; Schaltegger et al., unpublished, in Boekhout et al. 2012), yielding a mean ${ }^{206} \mathrm{~Pb} /{ }^{238} \mathrm{U}$ ratio of $0.09762 \pm 0.00012$ (95\% c.l., MSWD = 1.04). The calibration was controlled using Plešovice zircon as a secondary standard $\left({ }^{206} \mathrm{~Pb} /{ }^{238} \mathrm{U}\right.$ age of $337.13 \pm 0.37 \mathrm{Ma}$; Sláma et al. 2008); 12 out of 13 analyses yielded a mean ${ }^{206} \mathrm{~Pb} /{ }^{238} \mathrm{U}$ age of $338.8 \pm 1.1 \mathrm{Ma}(\mathrm{MSWD}=1.3)$. No common lead correction was applied due to the presence of ${ }^{204} \mathrm{Hg}$ in the system. Data are presented in Table S2 of the electronic supplement, including the data of the primary and secondary standards.

\section{Trace element analysis in zircon}

The trace element fraction, including $\mathrm{Zr}$ and $\mathrm{Hf}$, was collected after zircon ion exchange chemistry and trace elements analyzed following the TIMS-TEA method described in Schoene et al. (2010) on a Thermo Scientific ELEMENT 2 at ETH Zürich. Data are summarized in Table $\mathrm{S} 3$. In situ trace element analyses of zircon were carried out by laser ablation ICP-MS on representative zircons of the same zircon population as dated by U-Pb techniques, utilizing a Thermo Scientific ELEMENT XR coupled to a New Wave ArF $193 \mathrm{~nm}$ laser at University of Lausanne, the results are summarized in Table $\mathrm{S} 4$.

\section{Zircon Hf isotope analysis}

Hafnium isotopic compositions were analyzed from the same solution as trace elements (see previous section), using a Thermo-Fisher NEPTUNE multi-collector inductively coupled plasma mass spectrometer (MC-ICP-MS) at Johann Wolfgang Goethe University Frankfurt. For sample introduction, an Aridus desolvating nebulizer was employed (Gerdes and Zeh 2009; Wotzlaw et al. 2013). Results are summarized in Table S5. The accuracy of the results have been assessed by repeated measurements of JMC475 standard solution, yielding a mean ${ }^{176} \mathrm{Hf} /{ }^{177} \mathrm{Hf}$ ratio of $0.282148 \pm 0.000005(2 \sigma)$, and were subsequently normalized to ${ }^{176} \mathrm{Hf} /{ }^{177} \mathrm{Hf}=0.282160$. Six aliquots of a GJ-1 reference zircon solution were measured as an external standard as well, yielding an average of ${ }^{176} \mathrm{Hf} /{ }^{177} \mathrm{Hf}=$ $0.282016 \pm 0.000008(2 \sigma)$, which is in agreement with the overall mean ${ }^{176} \mathrm{Hf} /{ }^{177} \mathrm{Hf}$ value of $0.282010 \pm 0.000026$ ( $2 \sigma, N=\sim 900)$ from both laser and solution analyses at JWG University.

\section{Results}

\section{Zircon U-Pb geochronology by CA-ID-TIMS and LA-ICP-MS}

Individual zircon grains from one representative sample of each lithology in the VFC were selected for $\mathrm{U}-\mathrm{Pb} \mathrm{CA}-$ ID-TIMS analysis. Sample locations are shown in Fig. 1b; GPS coordinates are given in the caption of Fig. S1 (electronic supplement). Internal textures of a representative number of zircon crystals from each sample were imaged using cathodoluminescence (CL); a short description of these textures is presented in the electronic supplement, including the full set of CL images (Figs. S2 to S6). U$\mathrm{Pb}$ results of zircon are summarized in Fig. 3 and Table $\mathrm{S} 1$ (electronic supplement).

Analyzed zircon populations from both felsic and mafic samples consist of a minimum of 8 and a maximum of 16 dated grains per sample, which display dispersions of 93-205 ka for their ${ }^{206} \mathrm{~Pb} /{ }^{238} \mathrm{U}$ dates and does not allow the calculation of statistically significant weighted mean ages. Sample MFG contains two grains with ${ }^{206} \mathrm{~Pb} /{ }^{238} \mathrm{U}$ dates of around $42.73 \mathrm{Ma}$, likely recycled from an older magmatic pulse. The age distribution of dated zircon from all samples is very similar (Fig. 3), showing a dominant mode in the probability density distribution (PDD) curve at $\sim 42.5 \mathrm{Ma}$. Crystallization began at $\sim 42.6 \mathrm{Ma}$ (shared by 4 grains of VFT and PEG) and ended with a minor crystallization peak at $\sim 42.45 \mathrm{Ma}$. The fact that all six samples from both felsic and mafic lithologies describe very similar PDD curves suggests that all analyzed zircons share the same thermal 


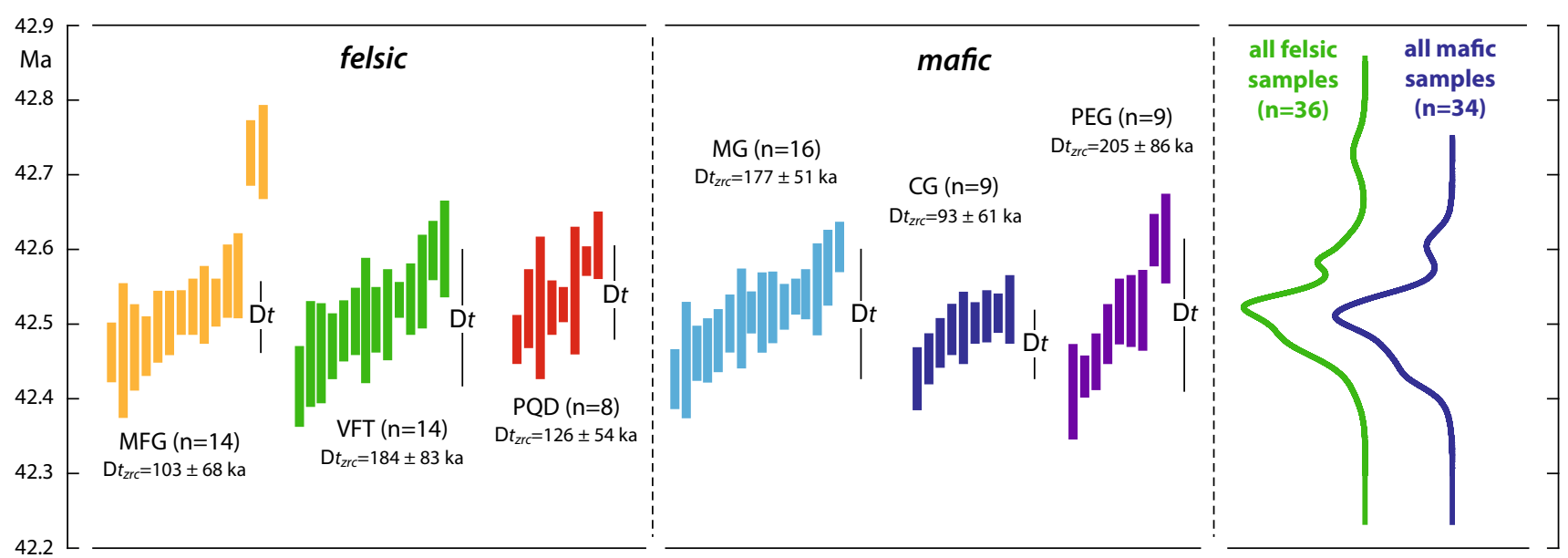

Fig. 3 Age-ranked plots showing ${ }^{206} \mathrm{~Pb} /{ }^{238} \mathrm{U}$ dates for zircon from the six studied samples. Summary PDD curves for felsic and mafic samples show very similar shapes with a dominant mode at $42.5 \mathrm{Ma}$, pointing to a very similar temperature-time evolution

evolution, i.e., the same periods of cooling and zircon crystallization. Sample PEG, a late-stage pegmatoid melt (Fig. S1f) contains both an older zircon with a ${ }^{206} \mathrm{~Pb} /{ }^{238} \mathrm{U}$ date of $42.61 \mathrm{Ma}$ and the youngest zircons at $42.41-42.43 \mathrm{Ma}$, pointing out that late-stage melts have sampled zircon crystals from previously crystallized magma pulses, and also host the latest zircon crystallization.

The CA-ID-TIMS ${ }^{206} \mathrm{~Pb} /{ }^{238} \mathrm{U}$ dates of 16 individual zircon grains from the MG sample spanning a range from $42.603 \pm 0.033$ to $42.426 \pm 0.039$ Ma deserve a special mention. These data cannot reproduce previously published results of U-Pb age determinations obtained by LA-ICPMS, which indicate the presence of xenocrystic cores that range from $51.0 \pm 1.1 \mathrm{Ma}$ to $43.9 \pm 1.2 \mathrm{Ma}$, and record ages of $40.3 \pm 1.0 \mathrm{Ma}$ for zircon rims and euhedral grains (Tiepolo et al. 2011). To further clarify this apparent disagreement, LA-ICP-MS U-Pb age determinations have been carried out on 38 zircon crystals from two additional samples of Mattoni gabbro (AD9 and CS23, see Fig. S1g, h). A total of 43 out of 45 analyses from zircons of both samples yielded a statistically significant population with a weighted mean ${ }^{206} \mathrm{~Pb} /{ }^{238} \mathrm{U}$ date of $41.75 \pm 0.14 \mathrm{Ma}$ $(\mathrm{MSWD}=1.9$; Table S2 and Fig. S7a). This date is $\sim 1.5 \%$ younger than the youngest high-precision date obtained by CA-ID-TIMS, possibly reflecting the effect of postcrystallization lead loss in non-chemically abraded, laserdated zircons, and corroborates the estimated general $2 \%$ external reproducibility limit of LA-ICP-MS U-Pb dating (Schaltegger et al. 2015).

These findings clearly do not agree with the LA-ICP-MS data of Tiepolo et al. (2011), who claim to find a 10-Malong history of zircon crystallization in their dated samples. This disagreement motivated us to carry out a careful reevaluation of the analytical data from their 2011 study (see
Fig. S8 in electronic supplement). Their data were acquired during two analytical sessions (July and October); the July session is analytically sound and yielded a mean ${ }^{206} \mathrm{~Pb} /{ }^{238} \mathrm{U}$ age of $41.32 \pm 0.47 \mathrm{Ma}$ for 40 spots $(\mathrm{MSWD}=2.5$; Fig. S8a), identical with our data within analytical uncertainties. The quality of the calibration of the October session is, however, inadequate to produce data from an unknown sample (see detailed presentation of arguments and Fig. S8c in electronic supplement): As a consequence, ${ }^{206} \mathrm{~Pb} /{ }^{238} \mathrm{U}$ dates of zircon from sample Mat3 show analytical scatter over $\sim 20 \%$, testified by unsystematic core-rim relationships (see Fig. S8b). More recently, the published data from another sample (Mat4; Tiepolo et al. 2014) show very similar scatter. In the latter case, however, an evaluation of the analytical quality is impossible, because no primary nor secondary standard data are published (see formulated request for publishing standard data in Schaltegger et al. 2015). Based on the scatter of the data from 91500 standard and sample zircons, we conclude that the Mat3 data set of Tiepolo et al. (2011) does not meet minimal requirements regarding the precision of both the calibration (i.e., of the relative sensitivity factor applied to the sample zircons) and the analysis of the sample itself. On technical-analytical grounds, the postulated $10 \mathrm{Ma}$ age span can therefore not be used for a geological interpretation.

\section{Trace element compositions of zircons}

Results from TIMS-TEA and laser ablation ICP-MS analyses

Trace element concentrations were analyzed from the same volume of zircon used for $\mathrm{U}-\mathrm{Pb}$ age determinations, described as TIMS-TEA by Schoene et al. (2010). Zircon 
Fig. 4 Chondrite-normalized rare earth element patterns for zircon, comparison between TIMS-TEA and LA-ICP-MS core and rim analyses. Zircons from the pegmatite sample were only analyzed by TIMS-TEA

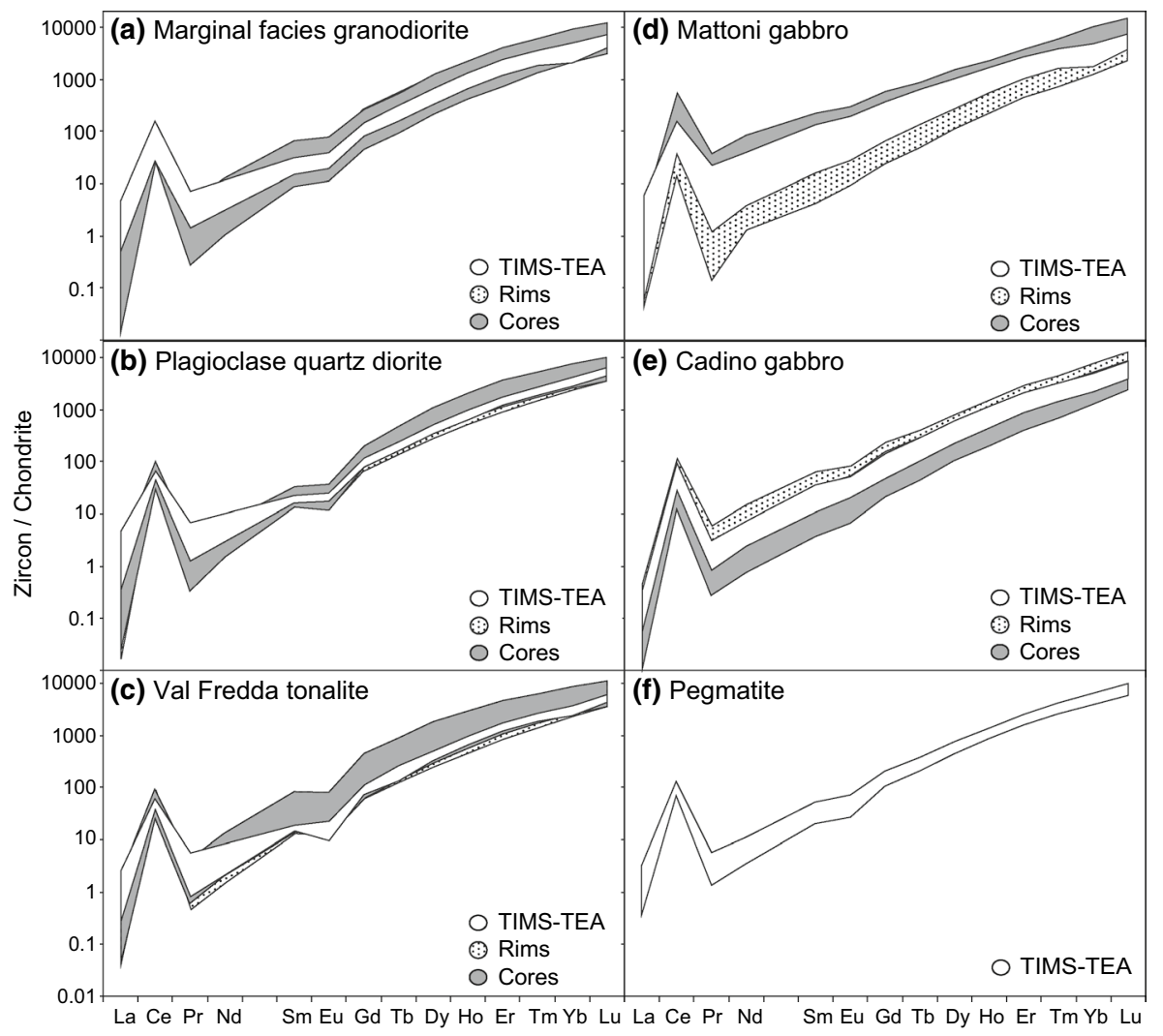

trace and rare earth element data together with the results of spatially resolved in situ analyses using LA-ICP-MS (see below) are summarized in Figs. 4, 5, and 6, and Tables S3 and S4 (electronic supplement).

The chondrite-normalized REE patterns for zircon grains from felsic samples (Fig. $4 \mathrm{a}-\mathrm{c}$ ) are characterized by HREE enrichment $\left[(\mathrm{Lu} / \mathrm{Gd})_{N} \sim 40-70\right]$, positive $\mathrm{Ce}$ anomalies, and mostly negative $\mathrm{Eu}$ anomalies (Eu/ $\left.\mathrm{Eu}^{*} \sim 0.5\right)$. Zircon grains from the felsic samples record no significant differences in concentrations of major constituents, such as Hf (Figs. 5a, 6a) or Zr, which translates to rather homogenous $\mathrm{Zr} / \mathrm{Hf}$ ratios $~ 40-60$, typical for calc-alkaline intermediate to felsic rocks (Pupin 2000) and contrasts with more variable element ratios such as $\mathrm{Y} / \mathrm{Hf},(\mathrm{Lu} / \mathrm{Gd})_{N}, \mathrm{Th} / \mathrm{U}$ and Nb/Zr (see Table S4). Based on the observed trace element variations in zircon, the individual felsic units cannot be clearly distinguished nor do they record coherent fractional crystallization trends through time (Fig. 6), as observed in the more voluminous, northerly Lago della Vacca complex (Schoene et al. 2012). We interpret the lack of correlation between trace element concentrations and ratios with time to represent the coexistence of chemically distinct magma batches during zircon crystallization.

The zircon grains from the gabbro samples (MG, CG) have chondrite-normalized REE patterns enriched in HREE $\left[(\mathrm{Lu} / \mathrm{Gd})_{N} \sim 20-80\right]$, but are lacking a negative Eu anomaly indicating a possible absence of precursor plagioclase crystallization or the Eu-depletion being compensated for by abundant amphibole fractionation (Fig. 4d, e), which is required by the model of Tiepolo et al. (2011). Zircon from the pegmatite sample (Fig. 4f) on the other hand exhibits a weak negative $\mathrm{Eu}$ anomaly $\left(\mathrm{Eu} / \mathrm{Eu}^{*} \sim 0.7\right)$. Zircon grains from the mafic samples record rather homogenous concentrations of Hf (Fig. 6a) and $\mathrm{Zr}$ that are distinct for each unit, which translates to $\mathrm{Zr} / \mathrm{Hf}$ ratios typical for mantlederived rocks (60-75; MG) and calc-alkaline intermediate rocks (30-55; CG, PEG; Pupin 2000). In contrast, zircon trace element ratios such as $\mathrm{Th} / \mathrm{U}, \mathrm{Y} / \mathrm{Hf}$ and $(\mathrm{Lu} / \mathrm{Gd})_{N}$ vary over a factor of two to three among the mafic samples. The two gabbros may be distinguished on the basis of $\mathrm{Hf}$ concentrations (Figs. 5a, 6a) or $\mathrm{Th} / \mathrm{U}-(\mathrm{Lu} / \mathrm{Gd})_{N}$ co-variation (Fig. 5c).

The major advantage of analyzing trace elements by TIMS-TEA is obtaining trace element information from the exact same volume of zircon we have high-precision temporal information from. Despite this obvious advantage, we also carried out complementary laser ablation ICP-MS trace element analyses on 10-20 representative zircon crystals per sample, mainly to obtain significant $\mathrm{Ti}$ concentrations for Ti-in-zircon thermometry. Trace element analysis by LA-ICP-MS was optimized for a small beam diameter of $25 \mu \mathrm{m}$ for sampling separately core and rim of zircon crystals pre-imaged by CL (see CL images 

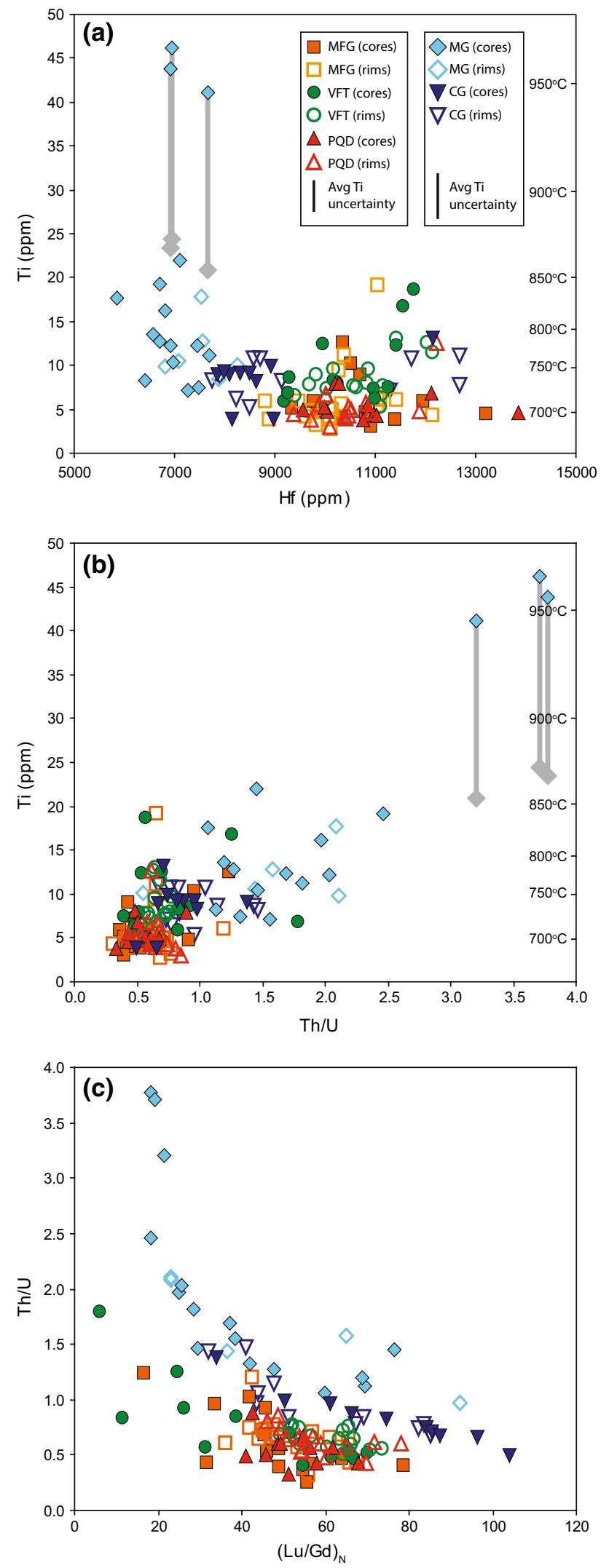

4 Fig. 5 LA-ICP-MS trace element data for cores and rims of zircon crystals from the same population of zircon as used for CA-IDTIMS dating. a Ti versus Hf; b Ti versus $\mathrm{Th} / \mathrm{U}$. Ti is indicated both in ppm and calculated as Ti-in-zircon temperature (Ferry and Watson 2007). Three MG cores are recalculated for $a_{(\mathrm{SiO} 2)}$ of 0.5 (gray diamonds); $\mathbf{c} \mathrm{Th} / \mathrm{U}$ versus $(\mathrm{Lu} / \mathrm{Gd})_{N}$

in Figs. 7, S2-S6, and LA-ICP-MS trace element data in Table S4; electronic supplement). In the case of MFG zircon grains, there is virtually no variation in REE patterns between core and rim analyses, and the TIMS-TEA analyses corresponds to the average between the core and rim concentrations (Fig. 4a). Zircons from PQD, VFT and MG exhibit trends of decreasing REE concentrations from cores to rims (Figs. $4 \mathrm{~b}-\mathrm{d}$ ), whereas CG shows the opposite trend (Fig. 4e). The distinctive feature of the mafic zircons is their lack of an Eu anomaly in both cores and rims (Fig. 4d, e). REE concentrations of the whole zircon volume by the TIMS-TEA method mainly correlate with the REE concentrations corresponding to the rim analyses. This reflects

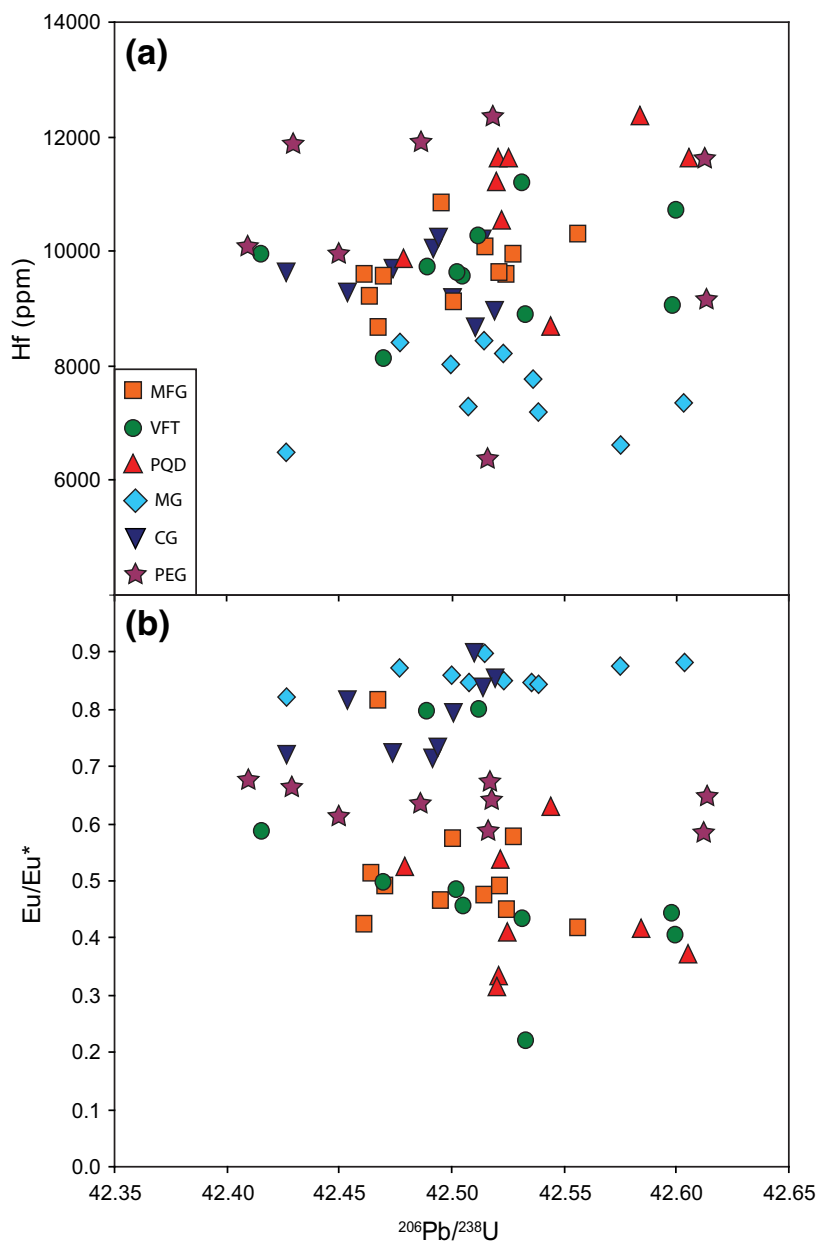

Fig. 6 a Variation of $\mathrm{Hf}$ concentrations and $\mathbf{b}$ of $\mathrm{Eu} / \mathrm{Eu}^{*}$ ratio in zircon through time (TIMS-TEA single-grain bulk analyses) 

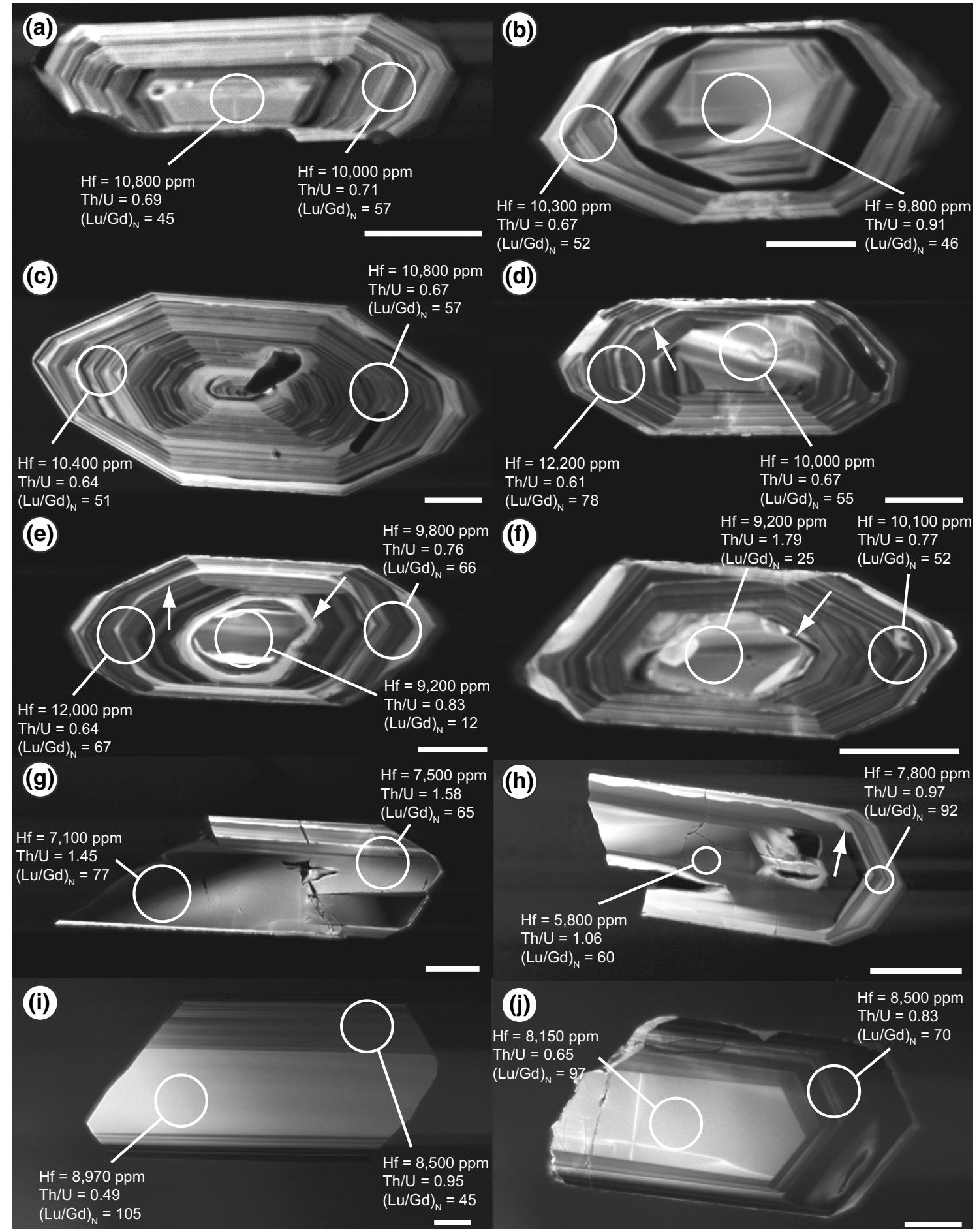

Fig. 7 Representative cathodoluminescence images of zircon showing locations of trace element analysis spots and corresponding trace element data. a MFG type 1 zircon; b MFG type 2 zircon, c PQD type 1 zircon; $\mathbf{d}$ PQD type 2 zircon; e VFT type 1 zircon; $\mathbf{f}$ VFT type

the fact that the trace element concentrations measured by TIMS-TEA are weighted toward the larger volume of the rim portion of the grains.
2 zircon; $\mathbf{g}$ MG type 1 zircon; $\mathbf{h}$ MG type 2 zircon; i CG type 1 zircon; j CG type 2 zircon. Arrows point to resorption fronts. Zircon types are described in the electronic supplement

Summarizing our observations, we recognize that zircon records a complex history of multiple periods of growth and dissolution within individual magma batches, generally 
more complex for the felsic members (Fig. 7a-f) than for the gabbro samples (Fig. $7 \mathrm{~g}-\mathrm{j}$ ). The VFT zircon crystal depicted in Fig. 7e shows several phases of resorption. Despite the observed differences in CL textures, only minor variations in trace element concentrations and ratios may be observed between the felsic units (Fig. 5). While the felsic units cannot be discriminated on the basis of zircon chemistry, individual zircons record inter-grain variations pointing to changes in both composition (e.g., $(\mathrm{Lu} / \mathrm{Gd})_{N}$, $\mathrm{Th} / \mathrm{U}$ ) and temperature (e.g., Ti) during crystallization (Fig. 5a, b). The lack of monotonic trends between cores and rims, and the large and non-systematic scatter in the trace element concentrations points to zircon crystallization from contrasting co-existing magma batches. Intra-grain variability in Ti may as well indicate temperature fluctuations during growth (Table S4). There is a weak trend of zircon cores recording larger trace element variations than rims (e.g., for $\mathrm{Ti}$, Hf concentrations, or for $\mathrm{Th} / \mathrm{U}$ ), suggesting that the cores crystallized from more chemically distinct magma batches, prior to amalgamating them into compositionally more uniform, bigger magma portions, represented by compositionally more uniform rim growth (see, e.g., Wotzlaw et al. 2014a).

Zircons from Mattoni and Cadino gabbros record less complex growth histories as observed by planar and broad growth zones with little evidence for dissolution (Fig. $7 \mathrm{~g}-$ j). Zircons from the two gabbros show distinct chemical evolution trends, with higher $\mathrm{Ti}$ and $\mathrm{Th} / \mathrm{U}$ and lower $\mathrm{Hf}$ and $(\mathrm{Lu} / \mathrm{Gd})_{N}$ in $\mathrm{MG}$ compared to CG zircon (Fig. 5a-c). The negative correlation between $\mathrm{Th} / \mathrm{U}$ and $\mathrm{Lu} / \mathrm{Gd}$ possibly points to concurrent fractionation of high- $\mathrm{Th} / \mathrm{U}$ and LREE-enriched titanite typical of Mattoni gabbro (Broderick 2013) and zircon in a cooling magma (Fig. 5c). However, core-rim analyses of gabbro zircons also record nonsystematic intra-grain variability, suggesting that gabbro zircons are also recording non-systematic fluctuating conditions during crystallization.

\section{Ti-in-zircon thermometry}

The application of the Ti-in-zircon thermometer (Watson and Harrison 2005; Watson et al. 2006; Ferry and Watson 2007) has been shown to be a valuable tool in constraining the temperatures at which zircon crystallizes in evolving magmas (Fu et al. 2008; Grimes et al. 2009; Claiborne et al. 2010; Ickert et al. 2010; Reid et al. 2010). The thermometer, which is based on the incorporation of Ti into zircon as a function of temperature, requires the knowledge of both $\mathrm{SiO}_{2}$ and $\mathrm{TiO}_{2}$ activities in the melt in order to apply the thermometer accurately. Quartz is abundant in the VFC felsic samples and is occasionally present as inclusions in zircon. In the gabbros, zircon in thin section is mainly included in quartz and plagioclase, and occasionally contains quartz inclusions. The silica activity is therefore considered to be equal to 1 for all VFC samples, with the exception of three cores analyzed from the Mattoni gabbro yielding excessive temperatures of around $950{ }^{\circ} \mathrm{C}$ (Fig. 5a, b). Being crystallized from a more primitive melt enriched in $\mathrm{Ti}, \mathrm{Th} / \mathrm{U}$ and depleted in $\left.(\mathrm{Lu} / \mathrm{Gd})_{N}\right)$, prior to silica saturation, an estimated silica activity of 0.5 results in more likely crystallization temperatures of $\sim 850{ }^{\circ} \mathrm{C}$ (Table S4). Direct determination of Ti by TIMS-TEA on the dated volume of zircon has not been possible due to elevated Ti background in the used ICP-MS instrument; we therefore have no direct link between age and temperature. The absence of rutile and the presence of titanite and ilmenite in all VFC samples suggest a Ti activity between 0.5 and 0.9 . An estimated $a_{\mathrm{TiO} 2}$ of 0.7 has thus been applied to all samples, in the range of typical Ti activities in magmas (Hayden and Watson 2007). Varying the Ti activity by \pm 0.2 will change the calculated temperatures by $+33 /-25^{\circ} \mathrm{C}$ at $750{ }^{\circ} \mathrm{C}$.

All Ti-in-zircon temperatures calculated according to Ferry and Watson (2007) using $a_{\mathrm{TiO} 2}=0.7$ and $a_{\mathrm{SiO} 2}=1$ yield variable temperatures (Table S4) with no clear correlations between cores and rims (Fig. 5a, b). Measured Ti-in-zircon temperatures are highest in MG $\left(750-900{ }^{\circ} \mathrm{C}\right)$ and lower in CG $\left(700-800{ }^{\circ} \mathrm{C}\right)$ and felsic samples $(680$ $850{ }^{\circ} \mathrm{C}$ ). The MG is the only lithology showing a trend of decreasing Ti-in-zircon temperatures with increasing $\mathrm{Hf}$ concentration and decreasing $\mathrm{Th} / \mathrm{U}$ ratios (Fig. 5d, e). In all other samples (CG, MFG, VFT, PQD), there is no clear correlation of Ti-in-zircon temperatures with other trace elements (Fig. 5a, b) nor a systematic decrease from cores to rims of analyzed zircon crystals.

Zircon saturation temperatures were calculated using the experimental calibration of Watson and Harrison (1983), and residual melt compositions were calculated from the whole-rock composition through the use of mass balance equations constrained by the experimental data of Piwinskii and Wyllie (1968), as described by Verberne (2013). This approach yields zircon saturation temperatures of $830-850{ }^{\circ} \mathrm{C}$ for the MFG; $~ 850-870{ }^{\circ} \mathrm{C}$ for the VFT; and $850-900{ }^{\circ} \mathrm{C}$ for the $\mathrm{PQD}$, in agreement with the high temperatures $\left(>800{ }^{\circ} \mathrm{C}\right)$ obtained from Ti-in-zircon thermometry (Fig. 5a, b).

\section{Zircon Hf isotopic compositions}

Hf isotope compositions of zircons were obtained by solution MC-ICP-MS from the same volume of zircon used for trace element analysis and $\mathrm{U}-\mathrm{Pb}$ age determinations (Fig. 8). The isotopic data, including $\varepsilon \mathrm{Hf}$ values and Lu-Hf-depleted mantle model ages $\left(t_{\mathrm{DM}}\right)$, are presented in Table S5 (electronic supplement); histograms comparing the $\varepsilon \mathrm{Hf}$ values of this study with previously published data from Mattoni gabbro (Tiepolo et al. 2014) are given in 
Fig. 8 a Hf isotopic compositions and $\mathrm{Th} / \mathrm{U}$ ratios from the same volume of zircon; b zircon Hf isotopic compositions indicating variable mixing between juvenile and crustal sources unrelated to the lifetime of the magmatic system; symbols as in Fig. 6

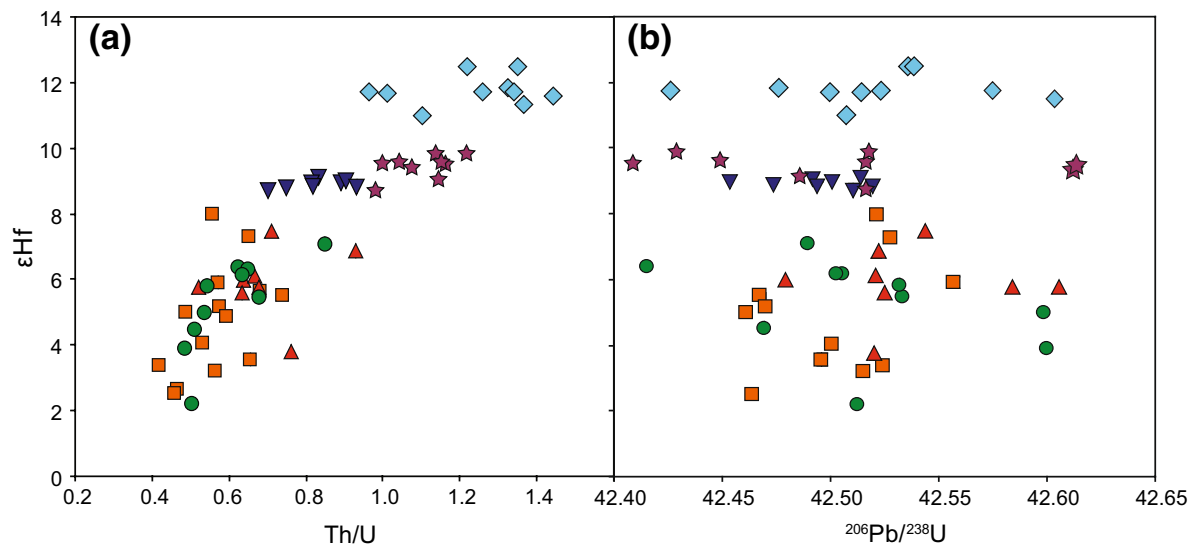

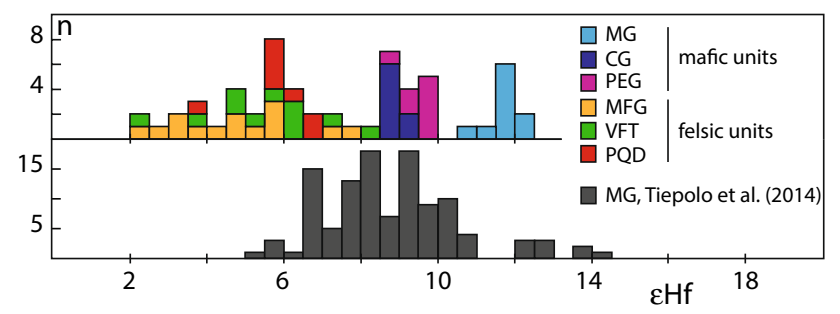

Fig. 9 Histogram of $\varepsilon \mathrm{Hf}$ values of this study (obtained by solution ICP-MS analysis from dated zircon grains), compared to LA-ICP-MS analyses from Tiepolo et al. (2014)

Fig. 9. Zircon grains from the VFC show considerable variation in $\mathrm{Hf}$ isotopic composition, $\varepsilon \mathrm{Hf}$ varying from +2.2 to +12.5 (Fig. 8a, b), suggesting mixing of at least two source components involved in the generation of the VFC magmas. The $\varepsilon \mathrm{Hf}$ values decrease with decreasing $\mathrm{Th} / \mathrm{U}$, pointing to increased mixing between more juvenile and crustderived melt batches prior to concurrent crystallization of zircon and high-Th/U titanite. Zircons from the felsic units (MFG, PQD, VFT) have initial Hf isotopic composition that range between $\varepsilon \mathrm{Hf}$ values of +2.2 and +8 , pointing to a subordinate crustal contribution. The mafic zircons from the VFC show less variation in their initial Hf isotopic compositions in comparison with the felsic units. Our solution $\mathrm{Hf}$ isotopic analyses form two distinct ranges of $\varepsilon \mathrm{Hf}$ values, (1) Mattoni gabbro (sample MG) from +11.3 to +12.5 and (2) Cadino gabbro (CG) and Pegmatite (PEG) from +8.7 to 9.9. In contrast, laser ablation ICP-MS $\varepsilon \mathrm{Hf}$ data from Tiepolo et al. (2014) range from +5 to +11 , with a single value up to +14 (Fig. 9). Their sample Mat4 (amphibole gabbro) yields $\varepsilon \mathrm{Hf}$ results between +5.3 and +10.9 , significantly lower than our well-reproducible results of analogue sample MG. We believe that differences between the data sets are significant, a problem that will have to be addressed in further work.

\section{Discussion}

\section{Zircon U-Pb dates as recorders of the thermal evolution of a growing magmatic system}

The U-Pb data presented above indicate that zircons from both felsic and mafic units crystallized over some 100 $200 \mathrm{ka}$ (Fig. 3). The dispersions in our U-Pb zircon dates may reflect one or several of the following processes: (1) youngest zircons may have been affected by post-crystallization lead loss despite their treatment by chemical abrasion, (2) zircon dates may be biased by the incorporation of xenocrystic cores; or (3) the duration of zircon growth within the VFC magmas.

Based on the consistency of our ${ }^{206} \mathrm{~Pb} /{ }^{238} \mathrm{U}$ age distribution between the different samples, we exclude post-crystallization $\mathrm{Pb}$ loss as a reason for the age dispersion. Overlapping trace element concentrations from core-rim analyses (Fig. 5) argue against the existence of xenocrystic cores, despite the resorbed and truncated cores overgrown by euhedral rims visible in CL (Figs. 7, S2-S7). Zircon saturation in granodioritic liquids occurs roughly between 700 and $850{ }^{\circ} \mathrm{C}$ (e.g., Harrison et al. 2007). Formation of internal resorption surfaces therefore points to temperature and related $\mathrm{Zr}$ concentration fluctuations in the magma, with repeated cycling of temperatures below, and possibly even rising above the upper limit of zircon saturation. The zircon age distribution (probability density) curves are thus a direct measure of the temperature evolution of a magmatic system. Since periods of enhanced zircon crystallization are strongly correlated between felsic and mafic units (common modes in the two probability density curves), we suggest that zircons from the different VFC units record a common thermal evolution. These peaks are very likely the consequence of magma injection pulses, leading to reduced zircon crystallization and possible zircon resorption due to overshooting of $\mathrm{T}_{\mathrm{sat}}$, and subsequent crystallization during cooling of the magma. 
Simple thermal modeling suggests that $\sim \mathrm{km}^{3}$ melt batches will reach the solidus within $10^{3}-10^{4}$ years' timescales, even when advecting additional heat by the injection of the mafic sheets (Broderick 2013). Since felsic and mafic lithologies display the same 100- to 200-ka-long zircon crystallization history within a single handspecimen, we suggest that most zircon crystals grew at depth were extracted from the deep crustal magma-processing zone, mixed and entrained in small batches of ascending magma that emplaced and solidified rapidly in the upper crust.

\section{Small melt batches in an immature magma system}

Our trace element and isotopic results from zircon of the VFC reveal no coherent temporal trace element correlations over 100-200 ka timescales, suggesting that the durations recorded by $\mathrm{U}-\mathrm{Pb}$ zircon dates do not record the crystallization of a single cooling magma volume.

Zircon in large volumes of convecting and homogenizing magma can record trace element trends typical of fractional crystallization. They may mimic liquid lines of descent during monotonic cooling, but also may be formed during cooling-rejuvenation cycles within a large, homogenous near-closed system (e.g., Wotzlaw et al. 2013). Th/U and $(\mathrm{Lu} / \mathrm{Gd})_{N}$ ratios in MG and CG zircons are the only recorders in the VFC of relatively coherent trace element trends that can be assigned to concomitant zircon and titanite fractionation within a mafic melt (Fig. 5c). This implies that titanite started to crystallize at temperatures significantly above the solidus, together with zircon. Zirconium concentrations of 1700-2000 ppm were reported from MG titanite (Broderick 2013), equivalent to a crystallization temperature of up to $800{ }^{\circ} \mathrm{C}$ (Hayden et al. 2008). The distinct difference in $\varepsilon \mathrm{Hf}$ from zircons from the Mattoni and Cadino gabbros $(+11$ to +12.5 vs. +8.7 to +9.1 , respectively) indicates that they crystallized as independent, hybrid magmas (Figs. 8b, 9).

Zircon from the felsic samples, on the other hand, exhibits a rather restricted range of trace element concentrations and ratios, which does not represent any systematic fractionation trends (Fig. 5), maybe with the notable exception of the VFT zircon cores in the Th/U-(Lu/Gd) $)_{N}$ space (Fig. 5c). We therefore advocate the hypothesis that zircon in the felsic melts crystallized in non-homogenized, small melt batches that are hybrids which contain various proportions of melts derived from: (1) residual liquid from the fractionation of amphibole in mafic melts; (2) remelting and rejuvenation of the initial felsic intrusions; and (3) partial melts from surrounding crustal material at various proportions. Mixing between these melt batches was concomitant with fractional crystallization of zircon and titanite, identified by the $\varepsilon \mathrm{Hf}-\mathrm{Th} / \mathrm{U}$ mixing trend visible in Fig. 8a between $\mathrm{MG}(\varepsilon \mathrm{Hf}=\sim+12), \mathrm{CG}(\varepsilon \mathrm{Hf}=\sim+9)$ and a "crustal" pole at $\varepsilon \mathrm{Hf}=\sim+2$. In addition, the zircons grew from different melt batches that differ in their degree of combined plagioclase-amphibole fractionation (Eu-anomaly; Fig. 4, 6b).

We therefore interpret the non-systematic trace element variations in zircon to represent the chemical variability within coexisting isolated magma batches.

\section{A conceptual model for the formation of the VFC}

There are two potential end-member scenarios for the crystallization of zircon in magmatic liquids: (1) crystallization at the final level of emplacement in the upper crust or (2) crystallization in an evolving magma at lower levels of the crust. Any model has to satisfy the chemical and isotopic characteristics of the analyzed zircon populations, as well as the observations in the field.

As discussed above, the prolonged 200-ka crystallization history and the common thermal evolution of mafic and felsic units are incompatible with crystallization in a single homogeneous upper-crustal magma body. The chemical and isotopic heterogeneities within and between felsic and mafic lithologies, rather point to small melt batches and separate reservoirs for the crystallization of zircons from felsic and mafic rocks that nevertheless share a common thermal history. The small volume of the magmatic system precludes zircon crystallization at shallow crustal levels over $200 \mathrm{ka}$. Clear contacts between felsic units as well as chilled margins on mafic sheets refute interpretations of repeated intrusion, remelting and incipient convective homogenization, as has been suggested for the LVC (Caricchi et al. 2012; Schoene et al. 2012). We therefore advocate a model, in which zircons from both felsic and mafic units record the thermal evolution of a multiply replenished lower-crustal magma-processing zone, as proposed for subrecent and recent volcanic systems (Claiborne et al. 2010; Cooper and Kent 2014). We therefore invoke that zircons in upper-crustal mafic plutonic rocks provide a window into processes active at deep crustal levels.

We draw a model for the "infant stage" of an orogenic pluton (Fig. 10), which never developed into a large, convecting magma chamber, but crystallized within a short period of time due to insufficient magma recharge.

\section{The initial melting stage}

Incipient magmatic activity starts building up a magma reservoir when hydrous mantle melts rise into the lower crust (at an estimated 25-30 km depth; Fig. 10a; Annen et al. 2006), in agreement with amphibole pressures of 0.8-1 GPa (Ulmer et al. 1983; Blundy and Sparks 1992; Nimis and Ulmer 1998; Tiepolo et al. 2011) and stall at the neutral buoyancy level. The melts start to crystallize 
(a) initial melting stage $\sim 42.6 \mathrm{Ma}$

(b) peak crystallization stage $\sim 42.5 \mathrm{Ma}$

(c) waning stage $\sim 42.45 \mathrm{Ma}$

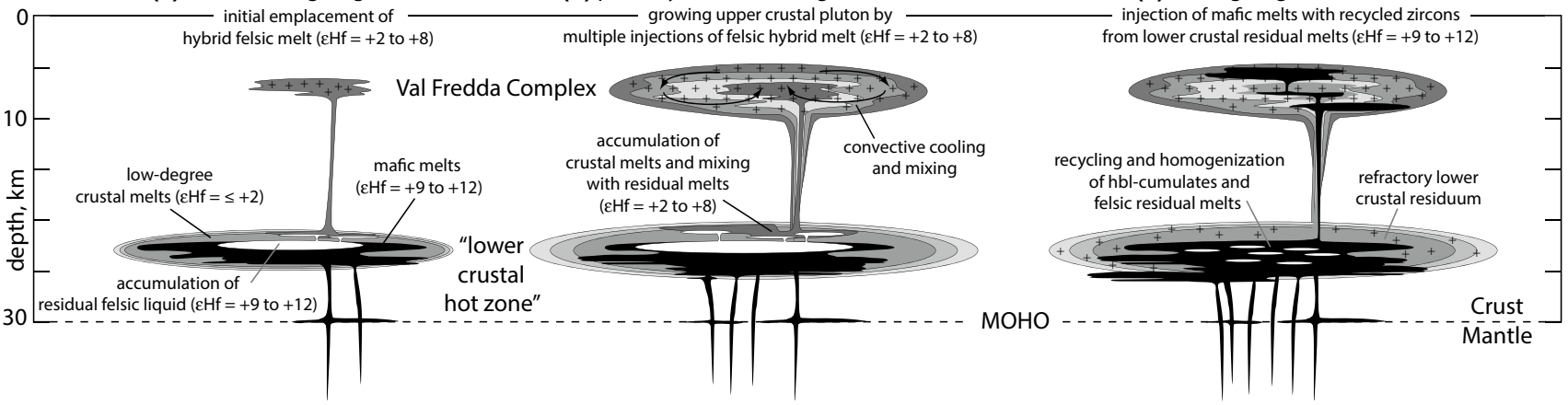

Fig. 10 A conceptual model for the evolution of the Val Fredda Complex through time. See text for discussion

mainly amphibole, which is observed as cumulates at the base of the Mattoni gabbro (e.g., Ulmer et al. 1983; Tiepolo et al. 2011) and segregate residual felsic melts. The residual felsic liquids mingle and mix to a great extent with small melt portions that formed after a short incubation time from remelting of the previously crystallized near-solidus crystal mush ("rejuvenation melts") and from melting of the surrounding lower crust ("partial crustal melts"; Annen et al. 2007). This process of incorporating lower-crustal melt is traced by zircon $\varepsilon \mathrm{Hf}$ values down to $\sim+2$. The isotopic signature that characterizes each melt batch has therefore been acquired in the deep crust by effective mixing of crustal melts with hot, more juvenile liquids. The lack of old inheritance in the analyzed zircons, which also valid for other southern Adamello units (Schaltegger et al. 2009; Schoene et al. 2012), points to conditions of melting and magma mixing that were consistently above the maximum temperature of zircon saturation. Some of these hybrid melts may already ascend into the upper crust at $6-10 \mathrm{~km}$ depth (Fig. 10a), while some others may have reached near-solidus conditions in the lower crust within short timescales.

\section{Peak crystallization stage ( 42.5 Ma)}

Keeping the melt flux from the mantle constant, incoming volumes of mafic melts produce a significant increase in temperature of the lower-crustal hot zone (Annen et al. 2007). Each rejuvenation cycle has the potential of producing a certain volume of volatile saturated and mobile (low-crystallinity) magma. These segregated volumes of granodioritic to tonalitic melts were sufficiently large, hot and buoyant to rise into the upper crust and form small, granodiorite to tonalite plutons. During the emplacement of these magmas, zircons that crystallized during earlier thermal cycles were resampled, with the main volume of zircon crystallizing at $\sim 42.5 \mathrm{Ma}$ (Figs. 3, 10b). In addition, upon emplacement, batches of hybrid, felsic melts formed in different parts of the magma zone, and subsequently mixed and mingled to some extent, but did not homogenize. This satisfies the observation that zircon with different chemical and isotopic characteristics were exchanged between batches, but maintaining sample-specific differences without achieving complete homogenization (Fig. 5).

\section{Waning stage}

The addition of a volatile-saturated mantle magma $\left(>1100{ }^{\circ} \mathrm{C}\right.$; Ulmer et al. 1983) to the magmatic system would mainly remelt crystals, which formed in earlier residual melts that were located in a hotter part of the magmatic system. The melts subsequently sampled previously crystallized olivines, pyroxenes, amphiboles and also zircons with juvenile Hf isotopic compositions, and then were emplaced into the upper crust. This magma intruded into almost completely solidified tonalite, as Mattoni gabbro sheets, but did not interact with crustal material during its ascent. A mantle origin of the Mattoni gabbro liquids is confirmed by radiogenic $\varepsilon \mathrm{Hf}$ values, as well as by a $\delta^{18} \mathrm{O}$ value of 5.34 permil for Mattoni zircon (Bindeman and Schaltegger, unpublished). Late-stage dykes collecting fragmented cumulate material from the root of a magmatic systems are known from a multitude of cases, even of peraluminous composition (e.g., Orano dykes of Elba; Farina et al. 2012), and are as well documented from later stages of the Adamello magmatism (picrite dykes of S. Adamello; Hürlimann et al., in press).

Part of these late mafic melts ascended rapidly through the roots of the magmatic system without interacting significantly with the cumulates, but very obviously experiencing a small degree of mixing with hybrid liquids to explain $\varepsilon \mathrm{Hf}$ values of $\sim+8$ to $\sim+9$, typical of Cadino gabbro zircon. The close spatial relationship with Mattoni melts, as well as the small involved magma volumes, preclude the existence of compositionally different parent melts. Amphibole 
and plagioclase crystallization was delayed until arrival at upper crustal levels, most likely for kinetic reasons (Blundy and Sparks 1992. Extraction of the residual liquid during rapid crystallization of plagioclase and acicular amphibole lead to the formation of volatile-saturated pegmatites. Since these are characterized by skeletal amphibole phenocrysts and yield the youngest recorded zircon dates at $\sim 42.45 \mathrm{Ma}$, we suggest that at least part of the zircons of sample PEG may have formed at emplacement level.

Our study of the VFC shows that the volume of the magmatic plumbing system was too small, and with a low integrated magma flux, it could not reach the state of a convective magma system, unlike the neighboring Lago della Vacca tonalite complex (Caricchi et al. 2012). In addition, the VFC system did not contain sufficiently mobile melt to feed a volcanic system at the surface at any time because the melt/crystal ratio of the magmatic systems was generally too low (Caricchi et al. 2014a, b). The magmatic storage zone in the lower crust increased its volume through the advection of mafic melts, while losing melt and heat escaping toward shallower crustal levels. Even at a constant recharge rate and a positive gain versus loss ratio, the melt flux was insufficient to maintain elevated temperatures, and the magmatic system cooled and crystallized entirely (e.g., Marsh 1981).

\section{Summary and conclusions}

The Val Fredda Complex (VFC) of the southern Adamello batholith is presented as an example of an orogenic magmatic system in its infant stage. Water-undersaturated mafic melts from a depleted mantle source intruded the deep crust and stalled at $30-25 \mathrm{~km}$ depth. Fractional crystallization of olivine, pyroxene and amphibole led to the formation of felsic residual melts, which interacted with near-solidus crystal mushes from earlier crystallization, forming rejuvenated melts (carrying abundant recycled crystal cargo). In addition, melting of surrounding crustal rocks led to the formation of partial melts with crustal isotope characteristics. Blending these different sources into a hybrid melt will cause the chemical and isotopic within-pluton heterogeneity observed in the VFC. The melting and blending of liquids appears to have happened at elevated temperatures above the saturation temperature for zircon, leading to the generally observed phenomenon of lacking inheritance in low- $\varepsilon$ Hf zircon in orogenic systems.

The fractional crystallization of hydrous basalt in the lower crust is responsible for producing cumulates of olivine, pyroxene and amphibole, and zircon, which then are rejuvenated and re-sampled by subsequent melts (e.g., Mattoni gabbro). Antecrysts from different melt portions get mixed together; the convective mixing is, however, not sufficient to lead to homogenization of the hybrid magmas. Any of these hybrid magmas potentially contains a mixture of earlier formed crystal cargo and newly crystallizing mineral phases, reflecting the change of melt composition through time.

The recorded 200-ka period of zircon growth precludes crystallization at emplacement level in the upper crust because magma volumes and fluxes are too small. The zircon age systematics are interpreted to record periods of lower temperature, during which parts of the magmatic systems arrived at zircon saturation. Batches from these melts were sequentially extracted and ascended into the upper crust where they solidified within $<20 \mathrm{ka}$ at paleodepths of $6-10 \mathrm{~km}$. The age dispersion of zircon and its compositional variation in our shallow-level pluton therefore allows us to reconstruct the deep-to-middle crustal processes otherwise not accessible to direct observation.

Acknowledgments This study was carried out as a part of the ProDoctoral school "Adamello 4-D", funded by the Swiss National Research Fonds and the Swiss University Conference (Proj. No. PDFMP2-123107). We thank all members of this ProDoc school for the continuous scientific exchange, and for awesome experiences in field and in the laboratory, and especially O. Müntener, P. Ulmer, P. Brack and L. Caricchi for many hours of discussion. M. Senn, M. Ovtcharova and A. Regnier are acknowledged for technical help during this research. We highly appreciate the extensive and challenging reviews of M. Tiepolo, C. Miller and J. Blundy, which helped us to improve the manuscript.

\section{References}

Annen C (2011) Implications of incremental emplacement of magma bodies for magma differentiation, thermal aureole dimensions and plutonism-volcanism relationships. Tectonophysics 500:3-10

Annen C, Blundy JD, Sparks RSJ (2006) The genesis of intermediate and silicic magmas in deep crustal hot zones. J Petrol 47:505-539

Annen C, Blundy JD, Sparks RSJ (2007) The sources of granitic melt in Deep Hot Zones. Trans. Royal Soc. Edinburgh, Earth Sci. 97:297-309

Blundy J, Sparks R (1992) Petrogenesis of mafic inclusions in granitoids of the Adamello Massif, Italy. J. Petrol 33:1039-1105

Boehnke P, Watson EB, Trail D, Harrison TM, Schmitt AK (2013) Zircon saturation re-revisited. Chem Geol 351:324-334

Boekhout F, Spikings R, Sempere T, Chiaradia M, Ulianov A, Schaltegger U (2012) Jurassic arc magmatism along the southern Peruvian margin during Pangea breakup and dispersal. Lithos 146-147:48-64

Bowring JF, McLean NM, Bowring SA (2011) Engineering cyber infrastructure for $\mathrm{U}-\mathrm{Pb}$ geochronology: tripoli and $\mathrm{U}-\mathrm{Pb}_{-}$ Redux. Geochem Geophys Geosyst 12:Q0AA19

Brack P (1983) Multiple intrusions-examples from the Adamello batholith (Italy) and their significance on the mechanism of intrusion. Mem Soc Geol Ital 26:145-157

Broderick C (2013) Timescales and petrologic processes during incremental pluton assembly: a case study from the Val Fredda Complex, Adamello Batholith, N. Italy. Unpublished $\mathrm{PhD}$ thesis No. 4612, Univ. of Geneva, Terre \& Environnement 125

Callegari E, Brack P (2002) Geological map of the Tertiary Adamello Batholith (Northern Italy) Explanatory notes and legend. Mem Sci Geol 54:19-49 
Caricchi L, Annen C, Rust A, Blundy J (2012) Insights into the mechanisms and timescales of pluton assembly from deformation patterns of mafic enclaves. J Geophys Res 117(B11):B11206

Caricchi L, Annen C, Blundy J, Simpson G, Pinel V (2014a) Frequency and magnitude of volcanic eruptions controlled by magma injection and buoyancy. Nat Geosci 7:126-130

Caricchi L, Simpson G, Schaltegger U (2014b) Zircons reveal magma fluxes in the Earth's crust. Nature 511:457-461

Cashman K, Blundy J (2013) Petrological cannibalism: the chemical and textural consequences of incremental magma body growth. Contrib Mineral Petrol 166:703-729

Chelle-Michou C, Chiaradia M, Ovtcharova M, Ulianov U, Wotzlaw J (2014) Zircon petrochronology reveals the temporal link between porphyry systems and the magmatic evolution of their hidden plutonic roots (the Eocene Coroccohuayco deposit, Peru). Lithos 198-199:129-140

Claiborne LL, Miller CF, Wooden JL (2010) Trace element composition of igneous zircon: a thermal and compositional record of the accumulation and evolution of a large silicic batholith, Spirit Mountain, Nevada. Contrib Mineral Petrol 160:511-531

Coleman DS, Gray W, Glazner AF (2004) Rethinking the emplacement and evolution of zoned plutons: geochronologic evidence for incremental assembly of the Tuolumne Intrusive Suite, California. Geology 32:433-436

Condon D, Schoene B, McLean NM, Bowring SA, Parrish RR (2015) Metrology and traceability of $\mathrm{U}-\mathrm{Pb}$ isotope dilution geochronology (EARTHTIME tracer calibration part I). Geochim Cosmochim Acta 164:464-480

Cooper KM, Kent AJR (2014) Rapid remobilization of magmatic crystals kept in cold storage. Nature 506:1-19

Cortecci G, Del Moro A, Leone G, Pardini GC (1979) Correlation between strontium and oxygen isotopic compositions of rocks from the Adamello Massif (Northern Italy). Contrib Mineral Petrol 68:421-427

de Saint Blanquat M, Horsman E, Habert G, Morgan S, Vanderhaeghe O, Law R, Tikoff B (2011) Multiscale magmatic cyclicity, duration of pluton construction, and the paradoxical relationship between tectonism and plutonism in continental arcs. Tectonophysics 500:20-33

Del Moro A, Pardini GC, Quercioli C, Villa IM, Callegari E (1983) $\mathrm{Rb} / \mathrm{Sr}$ and $\mathrm{K} / \mathrm{Ar}$ chronology of Adamello granitoids, southern Alps. Mem Soc Geol Ital 26:285-299

Farina F, Stevens G, Dini A, Rocchi S (2012) Peritectic phase entrainment and magma mixing in the late Miocene Elba Island laccolith-pluton-dyke complex (Italy). Lithos 153:243-260

Ferry JM, Watson EB (2007) New thermodynamic models and revised calibrations for the Ti-in-zircon and $\mathrm{Zr}$-in-rutile thermometers. Contrib Mineral Petrol 154:429-437

Fu B, Page FZ, Cavosie AJ, Fournelle J, Kita NT, Lackey JS, Wilde SA, Valley JW (2008) Ti-in-zircon thermometry: applications and limitations. Contrib Mineral Petrol 156:197-215

Gerdes A, Zeh A (2009) Zircon formation versus zircon alterationnew insights from combined $\mathrm{U}-\mathrm{Pb}$ and $\mathrm{Lu}-\mathrm{Hf}$ in situ LA-ICPMS analyses, and consequences for the interpretation of Archean zircon from the Central Zone of the Limpopo Belt. Chem Geol 261:230-243

Glazner AF, Bartley JM, Coleman DS, Gray W, Taylor RZ (2004) Are plutons assembled over millions of years by amalgamation from small magma chambers? GSA Today 14:4-12

Grimes CB, John BE, Cheadle MJ, Mazdab FK, Wooden JL, Swapp S, Schwartz JJ (2009) On the occurrence, trace element geochemistry, and crystallization history of zircon from in situ ocean lithosphere. Contrib Mineral Petrol 158:757-783

Hanchar JM, Watson EB (2003) Zircon saturation thermometry. Rev Miner Geochem 53:89-112
Hansmann W, Oberli F (1991) Zircon inheritance in an igneous rock suite from the southern Adamello batholith (Italian Alps). Contrib Mineral Petrol 107:501-518

Harrison TM, Watson EB, Aikman AB (2007) Temperature spectra of zircon crystallization in plutonic rocks. Geology 35:635-638

Hayden LA, Watson EB (2007) Rutile saturation in hydrous siliceous melts and its bearing on Ti-thermometry of quartz and zircon. Earth Planet Sci Lett 258:561-568

Hayden LA, Watson EB, Wark DA (2008) A thermobarometer for sphene (titanite). Contrib Mineral Petrol 155:529-540

Hürlimann N, Müntener O, Ulmer P., Nandedkar R, Chiaradia M, Ovtcharova M. Primary magmas in continental arcs and their differentiated products: petrology of a post-plutonic dyke suite in the Tertiary Adamello batholith (Alps). J Petrol (in press)

Ickert RB, Williams IS, Wyborn D (2010) $\mathrm{Ti}$ in zircon from the Boggy Plain zoned pluton: implications for zircon petrology and Hadean tectonics. Contrib Mineral Petrol 162:447-461

John BE, Blundy JD (1993) Emplacement-related deformation of granitoid magmas, southern Adamello Massif, Italy. Geol Soc Am Bull 105:1517-1541

Leuthold J, Müntener O, Baumgartner LP, Putlitz B, Ovtcharova M, Schaltegger U (2012) Time resolved construction of a bimodal laccolith (Torres del Paine, Patagonia). Earth Planet Sci Lett 325:85-92

Marsh BD (1981) On the crystallinity, probability of occurrence, and rheology of lava and magma. Contrib Mineral Petrol 78:85-98

Mattinson JM (2005) Zircon U-Pb chemical abrasion ("CA-TIMS") method: combined annealing and multi-step partial dissolution analysis for improved precision and accuracy of zircon ages. Chem Geol 220:47-66

Matzel JEP, Bowring SA, Miller RB (2006) Time scales of pluton construction at differing crustal levels: examples from the Mount Stuart and Tenpeak intrusions, North Cascades, Washington. Geol Soc Am Bull 118:1412-1430

McLean NM, Bowring JF, Bowring SA (2011) An algorithm for U$\mathrm{Pb}$ isotope dilution data reduction and uncertainty propagation. Geochem Geophys Geosyst. doi:10.1029/2010GC003478

Michel J, Baumgartner L, Putlitz B, Schaltegger U, Ovtcharova M (2008) Incremental growth of the Patagonian Torres del Paine laccolith over 90 ky. Geology 36:459-462

Miller CF, Furbish DJ, Walker BA, Claiborne LL, Koteas GC, Bleick HA, Miller JS (2011) Growth of plutons by incremental emplacement of sheets in crystal-rich host: evidence from Miocene intrusions of the Colorado River region, Nevada, USA. Tectonophysics 500:65-77

Nimis P, Ulmer P (1998) Clinopyroxene geobarometry of magmatic rocks Part 1: an expanded structural geobarometer for anhydrous and hydrous, basic and ultrabasic systems. Contrib Mineral Petrol 133:122-135

Piwinskii AJ, Wyllie PJ (1968) Experimental studies of igneous rock series: a zoned pluton in the Wallowa batholith, Oregon. J Geol $76: 205-234$

Pupin JP (2000) Granite genesis related to geodynamics from Hf-Y in zircon. Trans R Soc Edinb Earth Sci 91:245-256

Reid MR, Vazquez JA, Schmitt AK (2010) Zircon-scale insights into the history of a Supervolcano, Bishop Tuff, Long Valley, California, with implications for the Ti-in-zircon geothermometer. Contrib Mineral Petrol 161:293-311

Schaltegger U, Brack P, Ovtcharova M, Peytcheva I, Schoene B, Stracke A, Marocchi M, Bargossi GM (2009) Zircon and titanite recording 1.5 million years of magma accretion, crystallization and initial cooling in a composite pluton (southern Adamello batholith, northern Italy). Earth Planet Sci Lett 286:208-218

Schaltegger U, Schmitt AK, Horstwood MSA (2015) U-Th-Pb zircon geochronology by ID-TIMS, SIMS, and laser ablation 
ICP-MS: recipes, interpretations, and opportunities. Chem Geol 402:89-110

Schmitt AK (2011) Uranium series accessory crystal dating of magmatic processes. Annu Rev Earth Planet Sci 39:321-349

Schoene B, Latkoczy C, Schaltegger U, Günther D (2010) A new method integrating high-precision $\mathrm{U}-\mathrm{Pb}$ geochronology with zircon trace element analysis (U-Pb TIMS-TEA). Geochim Cosmochim Acta 74:7144-7159

Schoene B, Schaltegger U, Brack P, Latkoczy C, Stracke A, Günther D (2012) Rates of magma differentiation and emplacement in a ballooning pluton recorded by U-Pb TIMS-TEA, Adamello batholith, Italy. Earth Planet Sci Lett 355:162-173

Skopelitis A (2014) Formation of a tonalitic batholith through sequential accretion of magma batches: a study of chemical composition, age and emplacement mechanisms of the Adamello Batholith, N. Italy. Unpubl. PhD thesis no. 4660, University of Geneva

Sláma J, Košler J, Condon DJ, Crowley JL, Gerdes A, Hanchar JM, Horstwood MSA, Morris GA, Nasdala L, Norberg N, Schaltegger U, Schoene B, Tubrett MN, Whitehouse MJ (2008) Plešovice zircon-a new natural reference material for $\mathrm{U}-\mathrm{Pb}$ and $\mathrm{Hf}$ isotopic microanalysis. Chem Geol 249:1-35

Stauffacher AK (2012) Petrology and mineral chemistry of the Val Fredda Complex leucocratic units, Adamello, Italy. Unpubl. MSc thesis, ETH Zürich

Tiepolo M, Tribuzio R (2005) Slab-melting during Alpine orogeny: evidence from mafic cumulates of the Adamello batholith (Central Alps, Italy). Chem Geol 216:271-288

Tiepolo M, Tribuzio R, Vannucci R (2002) The compositions of mantle-derived melts developed during the Alpine continental collision. Contrib Mineral Petrol 144:1-15

Tiepolo M, Tribuzio R, Langone A (2011) High-Mg andesite petrogenesis by amphibole crystallization and ultramafic crust assimilation: evidence from Adamello hornblendites (Central Alps, Italy). J Petrol 52:1011-1045

Tiepolo M, Tribuzio R, Ji WQ, Wu FY, Lustrino M (2014) Alpine Tethys closure as revealed by amphibole-rich mafic and ultramafic rocks from the Adamello and the Bergell intrusions (Central Alps). J Geol Soc Lond 171:793-799
Ulianov A, Müntener O, Schaltegger U, Bussy F (2012) The data treatment dependent variability of $\mathrm{U}-\mathrm{Pb}$ zircon ages obtained using mono-collector, sector field, laser ablation ICPMS. J Anal At Spectrom 27:663

Ulmer P, Callegari E, Sonderegger UC (1983) Genesis of the mafic and ultramafic rocks and their genetical relations to the tonalitictrondhjemitic granitoids of the southern part of the Adamello batholith (Northern Italy). Mem Soc Geol Ital 26:171-222

Vazquez J, Reid M (2004) Probing the accumulation history of the voluminous Toba magma. Science 305:991-994

Verberne R (2013) The role of magma rheology during the emplacement of the Listino Suite, Adamello Massif, Italy. Unpubl PhD thesis, University of Lausanne

Watson EB, Harrison TM (1983) Zircon saturation revisited: temperature and composition effects in a variety of crustal magma types. Earth Planet Sci Lett 64:295-304

Watson EB, Harrison TM (2005) Zircon thermometer reveals minimum melting conditions on earliest Earth. Science 308:841-844

Watson EB, Wark DA, Thomas JB (2006) Crystallization thermometers for zircon and rutile. Contrib Mineral Petrol 151:413-433

Wotzlaw JF, Bindeman IN, Schaltegger U, Brooks CK, Naslund HR (2012) High resolution insights into episodes of crystallization, hydrothermal alteration and remelting in the Skaergaard intrusive complex. Earth Planet Sci Lett 355-356:199-212

Wotzlaw JF, Schaltegger U, Frick DA, Dungan MA, Gerdes A, Günther D (2013) Tracking the evolution of large volume silicic magma reservoirs from assembly to supereruption. Geology 41:867-870

Wotzlaw JF, Bindeman IN, Watts KE, Schmitt AK, Caricchi L, Schaltegger U (2014a) Linking rapid magma reservoir assembly and eruption trigger mechanisms at evolved Yellowstone-type supervolcanoes. Geology 42:807-810

Wotzlaw JF, Hüsing SK, Hilgen FJ, Schaltegger U (2014b) Highprecision zircon $\mathrm{U}-\mathrm{Pb}$ geochronology of astronomically dated ash beds from the Mediterranean Miocene. Earth Planet Sci Lett 407:19-34 